J. Amer. Soc. Hort. ScI. 127(4):608-615. 2002.

\title{
Quantitative Trait Loci (QTL) Analysis of Canning Quality Traits in Kidney Bean (Phaseolus vulgaris L.)
}

\author{
Maria-Carmela T. Posa-Macalincag ${ }^{1}$ \\ Department of Crop and Soil Sciences, Michigan State University, East Lansing, MI 48824
}

George L. Hosfield ${ }^{2,4}$

U.S. Department of Agriculture, Agricultural Research Service, Sugarbeet and Bean Research, Department of Crop and Soil Sciences, Michigan State University, East Lansing, MI 48824

Kenneth F. Grafton
Department of Plant Sciences, North Dakota State University, Fargo, ND 58105

Mark A. Uebersax ${ }^{3}$

Department of Food Science and Human Nutrition, Michigan State University, East Lansing MI 48824

James D. Kelly

Department of Crop and Soil Sciences, Michigan State University, East Lansing, MI 48824

\begin{abstract}
ADDITIONAL INDEX WORDS. Common bean, RAPD markers, major genes, composite interval mapping, genome, Phaseolus core map, linkage groups, canned bean appearance

Abstract. Canning quality of dry bean (Phaseolus vulgaris L.), of which the degree of splitting (SPLT) and overall appearance (APP) of canned beans are major components, is a complex trait that exhibits quantitative inheritance. The objectives of this study were to identify major genes that affect APP and SPLT in kidney bean, and map the location of these loci to the integrated core map of common bean. The analysis was performed using random amplified polymorphic DNA (RAPD) markers and two populations of kidney bean, consisting of 75 and 73 recombinant inbred lines (RILs), respectively. The two populations-'Montcalm' x 'California Dark Red Kidney 82' and 'Montcalm' x 'California Early Light Red Kidney'-were planted in six year-location combinations in Michigan, Minnesota and North Dakota from 1996 to 1999. Correlations between APP and SPLT were high (0.91 to 0.97). Heritability estimates for APP and SPLT ranged from 0.83 to 0.85 in the two populations. Major genes for these traits were identified on two linkage groups. The first QTL, associated with seven RAPD markers, was putatively mapped to the B8 linkage group of the core bean linkage map. Desirable canning quality appeared to be derived from Montcalm at this locus. The second QTL, associated with four markers, appeared to be derived from the California parents. The second linkage group was not assigned to a linkage group in the core map. Population and environment-specificity were observed for the markers identified.
\end{abstract}

Beans of the light and dark red kidney market classes account for $\approx 8 \%$ of the $1.44 \mathrm{Mg}$ production of dry edible bean (Phaseolus vulgaris L.) in the U.S. (Lucier et al., 2000). Light red kidney beans are used mainly in chili products, while the dark reds are a significant component of restaurant salad bars. Kidney bean cultivars must meet strict seed size, shape and color criteria, and have acceptable canning quality for commerce. Canning quality is a complex trait and is associated with influences that determine the hydration characteristics of seeds, thermal conditions that render seeds palatable and provide for the digestion of nutrients, and consumer and processor preferences (Adams and Bedford, 1975; Forney et al., 1990; Hosfield and Uebersax, 1980, 1990; Hosfield et al., 1984a; Uebersax and Bedford, 1980). Although physical and chemical attributes of cooked beans all contribute to processing quality, no single characteristic can adequately describe a sample (Hosfield, 1991; Hosfield and Uebersax, 1990). A number of tests have been

Received for publication 16 Jan. 2002. Accepted for publication 8 Apr. 2002. Names are necessary to report factually on available data; however, the USDA neither guarantees nor warrants the standard of the product, and the use of the name by the USDA implies no approval of the product to the exclusion of others that may be suitable. The authors thank Dechun Wang of the Department of Crop and Soil Sciences at Michigan State University for his assistance in the analysis using QTL Cartographer.

${ }^{1}$ Graduate research assistant.

${ }^{2}$ Research geneticist and adjunct professor.

${ }^{3}$ Professor.

${ }^{4}$ Corresponding author; e-mail hosfiel2@pilot.msu.edu. developed that describe the component nature of canning quality. Tests that measure traits such as general appearance, incidence of splitting, firmness, and washed drained weight are routinely used by breeders to assess canned bean quality (Hosfield and Uebersax, 1980; Hosfield et al., 1984a, 1984b; Wassimi et al., 1990).

Canning quality traits exhibit quantitative inheritance (Hosfield et al., 1984a; Walters et al., 1997; Wassimi et al., 1990). In quantitative trait analysis, the use of markers and genetic maps has permitted the breeder to identify regions of the genome that most likely contain the genes or groups of genes [quantitative trait loci (QTL)], responsible for the expression of complex traits. QTL mapping in dry bean has been successful for mostly disease resistance traits (Ariyarathne et al., 1999; Jung et al., 1999; Kelly and Miklas, 1998; Miklas et al., 1998, 2000, 2001; Park et al., 1999, 2001).

QTL for seed traits important in bean quality (size and shape) have been identified (Park et al., 2000). These traits are essential for classifying beans into distinct market classes, and they affect, to some degree, the expected canning quality of a market class. With regards to canning quality per se, Walters et al. (1997) identified several random amplified polymorphic DNA (RAPD) markers associated with component traits of canning quality in three populations of navy bean. Markers were linked to visual appeal (VIS), texture (TXT), and the washed drained weight (WDWT) of processed beans. Location and population specificity among the markerQTL associations were observed in the study. 
The mapping of loci associated with canning quality should be useful in kidney bean breeding programs. Accordingly, the objective of this study was to identify major genes that affect the expression of the canning quality traits, appearance (APP) and degree of splitting (SPLT). We also evaluated whether RAPD markers associated with visual appeal (same trait as APP in the current study) in navy bean (Walters et al., 1997) were useful in kidney bean. Our study was conducted in six environments spanning 4 years of production, which allowed us to evaluate the consistency of the marker-trait associations. The putative location of QTL detected in this study was mapped to the integrated core map of common bean (Freyre et al., 1998).

\section{Materials and Methods}

PLANT MATERIALS. Two recombinant inbred populations were derived from crosses between the dark red kidney bean cultivars 'Montcalm' (MCM) and 'California Dark Red Kidney 82' (CDRK 82), and MCM and 'California Early Light Red Kidney’ (CELRK). MCM (Copeland and Erdmann, 1977) has excellent canning quality. CDRK 82 has less desirable canning quality than MCM. CELRK is recognized as possessing favorable canning quality for a light red kidney but lacks the superior attributes of the dark red kidney, MCM.

Population 1, derived from a cross between MCM and CDRK 82 , consisted of 75 dark red kidney bean recombinant inbred lines (RILs). Population 2 comprised 73 RILs and was derived from a cross between MCM and CELRK. RILs were derived from single-plant $F_{2}$ selections advanced in the greenhouse using single-seed descent until the $\mathrm{F}_{6}$ generation. Seed from $\mathrm{F}_{6}$ plants was bulked, and increased in the field until the $\mathrm{F}_{8}$ generation. The seed types in Population 2 varied among dark and light red, and noncommercial intermediate RILs.

Field Plot PROCEDURes. For this study, the RILs of Populations 1 and 2 were grown in six experiments: Michigan (1996, 1997, 1998, 1999); Minnesota (1996) and North Dakota (1999). For the Michigan experiments, the 75 and 73 RILs and two parents of each respective population, and a number of checks to give 81 entries for each population were planted in a $9 \times 9$ balanced lattice with two replications (except for 1996 when three replications were used) on a McBride Sandy Loam (coarseloamy, mixed frigid Alfic Fragiothods) at the Montcalm Potato Research Farm near Entrican, Mich. In each experiment, entries were planted in two-row plots, $6.1 \mathrm{~m}$ long and spaced $0.5 \mathrm{~m}$ apart. The within row spacing was $\approx 8 \mathrm{~cm}$. Herbicide and fertilizer applications were made following recommendations made by the Michigan Dry Bean Production Research Advisory Board Agronomist. Mature plants of each of the 81 entries of each replication of each population were hand harvested from $4.6 \mathrm{~m}^{2}$ of a plot and threshed using an Almaco stationary plot thresher (1996-98) and a Hege 140 Plot Harvester (1999).

The respective RILs, parents and checks of each population were grown in lattices and replicated two times in a Hubbard sandy silt (sandy, mixed, frigid, Entic Hapludolls) near Perham, Minn., and in a Gardena silt (coarse-silty, mixed, superactive, frigid, Pachic Hapludolls) near Erie, N. Dak. At both locations, the entries were planted in two-row plots, $6.1 \mathrm{~m}$ long and spaced $0.8 \mathrm{~m}$ apart. Within row spacing was $\approx 8 \mathrm{~cm}$ at these locations. Mature plants were hand harvested from $6.0 \mathrm{~m}^{2}$ of plot and threshed with an Almaco Stationary Plot thresher. The threshed seed lots were sent to Michigan where they were evaluated for canning quality. In each year, the threshed seed were cleaned of plant debris, broken and/or diseased grains and soil particles, and sized using $4 \times 19-\mathrm{mm}$ slotted metal sieves and stored at $22^{\circ} \mathrm{C}$ and $75 \%$ RH until thermally processed.

Evaluation OF CANNING QUALITY. Before canning, seed moisture percentage was determined on $250 \mathrm{~g}$ of beans using a moisture meter. Duplicate samples from each plot with a freshweight equivalent of $100 \mathrm{~g}$ total solids (Hosfield and Uebersax, 1980) were placed in nylon mesh bags and soaked at $21^{\circ} \mathrm{C}$ for 30 min and blanched at $88^{\circ} \mathrm{C}$ for $30 \mathrm{~min}$. Soaking and blanching were done in distilled water adjusted to $0.025 \mathrm{~mol} \cdot \mathrm{L}^{-1}$ calcium ion (Hosfield and Uebersax, 1980; Uebersax and Bedford, 1980). The soaking and blanching procedures produced well-hydrated beans with minimum bean damage, similar to beans soaked and blanched in the high-temperature systems common throughout the U.S. canning industry (Hosfield and Uebersax, 1980).

After bean samples were blanched, each was immersed in tap water $\left(22^{\circ} \mathrm{C}\right)$ for $5 \mathrm{~min}$ to cool. Samples were drained, weighed, and filled into number $303(100 \times 75 \mathrm{~mm})$ tin cans and covered with boiling brine. The brine was prepared by adding $142.0 \mathrm{~g}$ sucrose, $113.4 \mathrm{~g}$ of $\mathrm{NaCl}$ to $9.1 \mathrm{~kg}$ of distilled water adjusted to $0.025 \mathrm{~mol} \cdot \mathrm{L}^{-1}$ calcium ion. The cans were exhausted at $90{ }^{\circ} \mathrm{C}$ for $5 \mathrm{~min}$ in a water filled exhaust box, sealed, and cooked in a commercial retort without agitation for $45 \mathrm{~min}$ at $116^{\circ} \mathrm{C}$ and 1.04 $\times 10^{5} \mathrm{~Pa}(15 \mathrm{psi})$. After the beans were thermally processed, the cans were removed from the retort, cooled under running tap water $\left(22^{\circ} \mathrm{C}\right)$ for $15 \mathrm{~min}$, and stored inverted for a minimum of 2 weeks at $22^{\circ} \mathrm{C}$ before any evaluations were made.

Subjective evaluations were made on the contents of each thermally processed can of beans (Hosfield and Uebersax, 1980; Walters et al., 1997). Beans were decanted into Styrofoam containers and evaluated by a team ( 7 to 12 persons) of trained judges. The judges rated bean samples for APP and SPLT on a 7point scale, as follows: 1 = very undesirable; 2 = moderately undesirable; 3 = slightly undesirable; 4 = neither desirable nor undesirable; $5=$ slightly desirable $;=$ moderately desirable; $7=$ very desirable. In the case of SPLT, a rating of 7 indicated that the sample had no broken or split beans, while a rating of 1 indicated that most of the beans in the sample were broken, burst, or severely split in the horizontal, vertical, or tangential planes. The APP and SPLT scores were averaged across judges for each sample.

RAPD MARKERS. DNA from five plants of each parent and each RIL, at the $\mathrm{F}_{6: 8}$ generation at the earliest, was extracted using the protocol reported by Walters et al. (1997). Polymerase chain reactions were performed in a DNA thermal cycler (model 480; Perkin Elmer Cetus) or a programmable thermal controller (PTC100; MJ Research, Inc.). Random primers were used (Williams et al., 1990), and the reaction conditions were as follows: $20 \mu \mathrm{L}$ reactions containing $1 \times$ buffer $(20 \mathrm{~mm}$ Tris- $\mathrm{HCl}, \mathrm{pH} 8.4 ; 50 \mathrm{~mm}$ $\mathrm{KCl}$ ), $3 \mathrm{~mm} \mathrm{MgCl}_{2}, 0.2 \mathrm{~mm}$ dNTPs, $20 \mathrm{ng}$ total genomic DNA, 20 ng primer and $1 \mathrm{U}$ Taq polymerase from Gibco BRL; 3 cycles of $1 \mathrm{~min}$ at $94^{\circ} \mathrm{C}, 1 \mathrm{~min}$ at $35^{\circ} \mathrm{C}, 2 \mathrm{~min}$ at $72{ }^{\circ} \mathrm{C} ; 34$ cycles of $10 \mathrm{~s}$ at $94{ }^{\circ} \mathrm{C}, 20 \mathrm{~s}$ at $40{ }^{\circ} \mathrm{C}, 2 \mathrm{~min}$ at $72{ }^{\circ} \mathrm{C}$, with a third segment extension of $1 \mathrm{~s}$ per cycle; and a 5-min extension at $72^{\circ} \mathrm{C}$. PCR products were resolved with 100-bp and $1 \mathrm{~kb}$ DNA ladders from Gibco BRL on a $1.4 \%$ agarose gel on $1 \times$ TAE buffer.

In total, 557 single decamer primers from Operon Technologies (Alameda, Calif.) were screened, 107 of which identified markers that are part of the core linkage map of common bean (Freyre et al., 1998). Mapped markers were used to help locate putative QTL associated with APP and SPLT on the integrated map. A combination of screening of the DNA of the parents and 
Table 1. Estimates of variance components, and the components scaled to sum to 100 for appearance (APP) of processed kidney bean in Populations 1 and 2, grown in Michigan, Minnesota and North Dakota from 1996 to 1999.

\begin{tabular}{|c|c|c|c|c|c|}
\hline \multirow[t]{3}{*}{ Population } & \multicolumn{5}{|c|}{ Variance component $\mathrm{t}^{\mathrm{z}, \mathrm{y}}$} \\
\hline & \multicolumn{5}{|c|}{ Analyses combined over 4 years in Michigan } \\
\hline & $\sigma_{E}^{2}(\%)$ & $\sigma_{\mathrm{R}}^{2}(\%)$ & $\sigma_{\mathrm{GXY}}^{2}(\%)$ & $\sigma_{\mathrm{Y}}^{2}(\%)$ & $\sigma_{\mathrm{G}}^{2}(\%)$ \\
\hline \multirow[t]{2}{*}{2} & $0.39(39.4)$ & $0.04(3.6)$ & $0.19^{* *}(19.2)$ & $0.02^{* *}(2.3)$ & $0.35^{* *}(35.4)$ \\
\hline & \multicolumn{5}{|c|}{ Analyses combined over six environments } \\
\hline 2 & $0.36(36.8)$ & $0.02(2.3)$ & $0.21^{* *}(21.7)$ & $0.03^{* *}(3.0)$ & $0.36^{* *}(36.3)$ \\
\hline
\end{tabular}

${ }^{\mathrm{z}} \mathrm{E}=$ error, $\mathrm{G}=$ genotype, $\mathrm{R}=$ replications, $\mathrm{Y}=$ year, $\mathrm{V}=$ environment (location and year confounded), $\mathrm{G} \times \mathrm{Y}=$ genotype $\times$ year interaction, $\mathrm{G} \times$ $\mathrm{V}=$ genotype $\times$ environment interaction.

yParentheses $=$ components scaled to sum to 100 .

${ }^{* *}$ Significant at $P=0.05$.

Statistical analysis. Correlations among the traits for each environment were determined using the program proc corr in SAS (SAS Institute, 1998). Heritability estimates were calculated on a progeny mean basis (Fehr, 1987), using data from two replications in all six environments. This heritability approximates a narrow-sense estimate because coefficients for nonadditive genetic components in the expectation of genetic variance are near zero for $\mathrm{F}_{8}$-derived lines (Hallauer and Miranda, 1981). Confidence intervals for heritability estimates were derived according to Knapp et al. (1985).

Chi-square tests on the segregation ratio of the putative markers were conducted for the two populations. Linkages between markers that segregated according to a 1:1 ratio were determined using Mapmaker (Lander et al., 1987). Linkage was considered significant if the logarithm of odds (LOD) score was $\geq 4.0$. Centimorgan distances were based upon recombination fractions (Kosambi, 1944). For each environment and the average over all environments, two methods were used to detect quantitative trait loci. For the first method, significant associations between single markers and the plot mean scores for canning quality traits were detected by single-factor analysis of variance using the SAS program (SAS Institute, 1998). Significance levels were set at 0.05 for acceptance of marker-trait associations. Groups of markers were also analyzed using ANOVA.

The second QTL detection method was composite interval side by side on an agarose gel to identify the markers.

Table 2. Means and ranges of scores for appearance of processed beans of parents and RILs of Populations 1 and 2, planted in six environments.

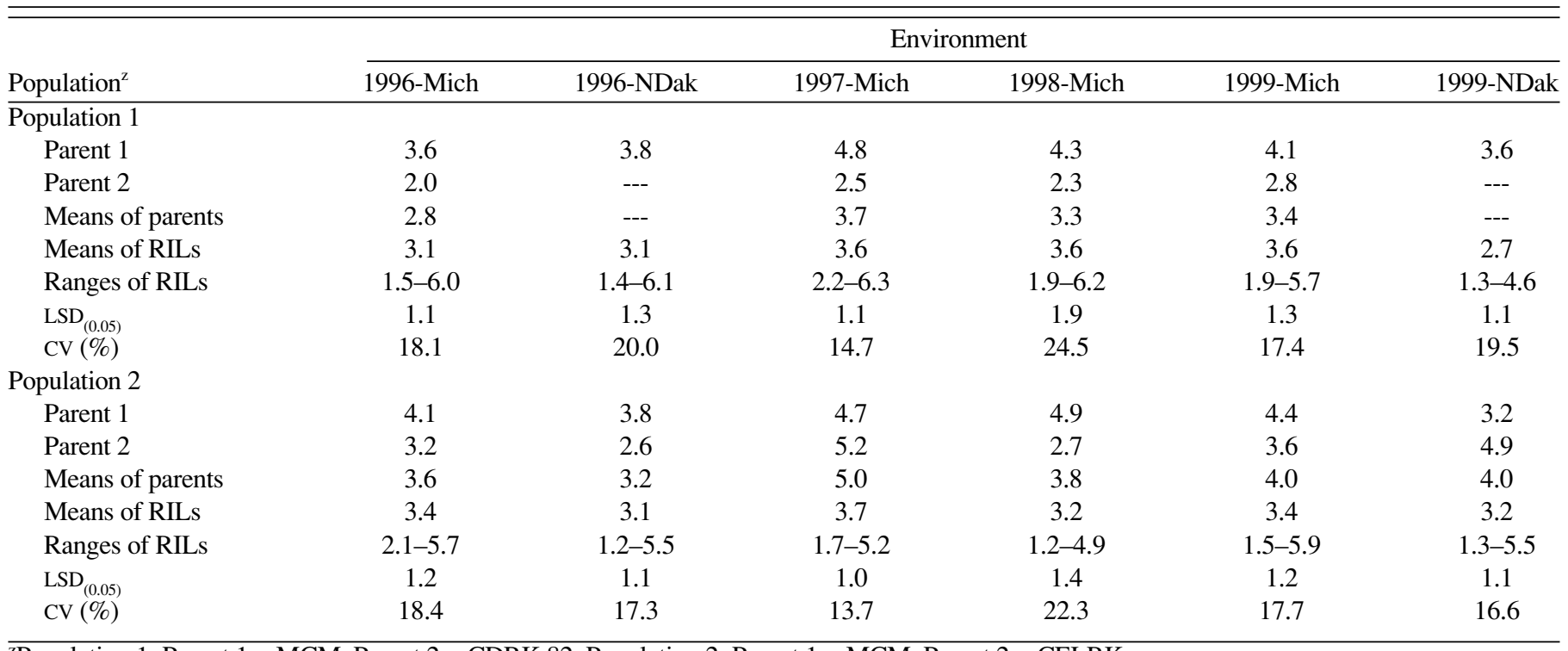

${ }^{\mathrm{Z} P o p u l a t i o n ~ 1: ~ P a r e n t ~} 1$ = MCM, Parent 2 = CDRK 82. Population 2: Parent 1 = MCM, Parent 2 = CELRK. 
Table 3. Narrow-sense heritability estimates for appearance and degree of splitting of processed beans in Populations 1 and 2.

\begin{tabular}{lll}
\hline \hline Population & Appearance $(\mathrm{CI})^{\mathrm{z}}$ & Degree of Splitting $(\mathrm{CI})^{\mathrm{z}}$ \\
\hline 1 & $0.83(0.75-0.87)$ & $0.84(0.76-0.87)$ \\
2 & $0.85(0.77-0.89)$ & $0.85(0.78-0.89)$
\end{tabular}

${ }^{\mathrm{z}} \mathrm{CI}=$ confidence interval of $\mathrm{h}^{2}$ estimate.

\section{A. LG1 Population 1 APP}

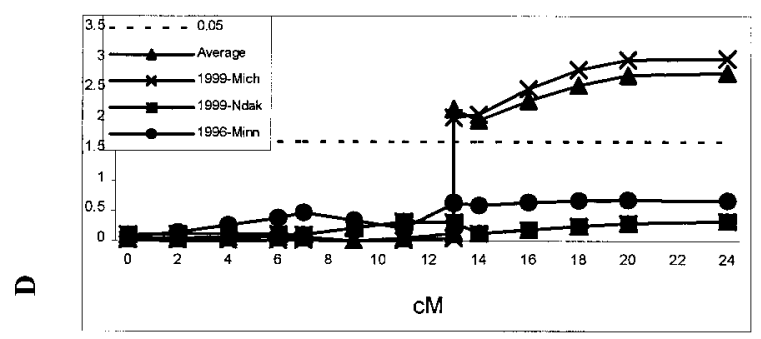

8

B. LG1 Population 1 SPLT

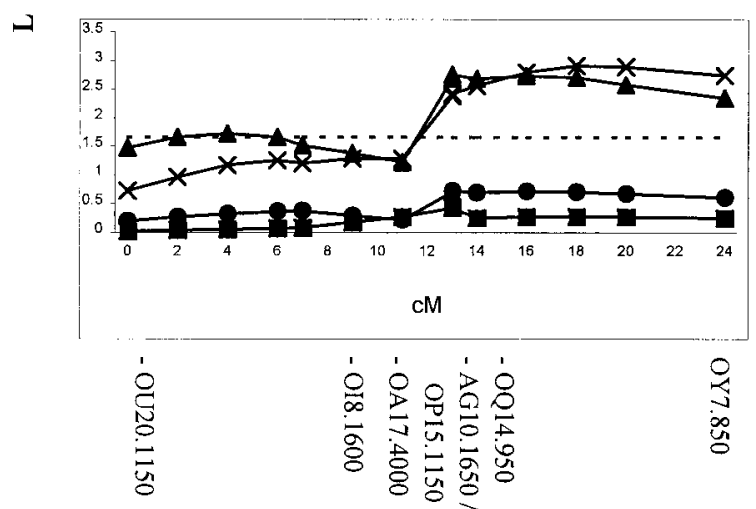

C. LG1 Population 2 APP

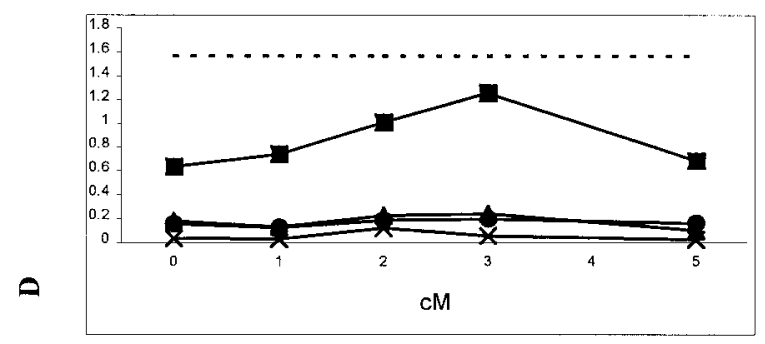

0

D. LG1 Population 2 SPLT

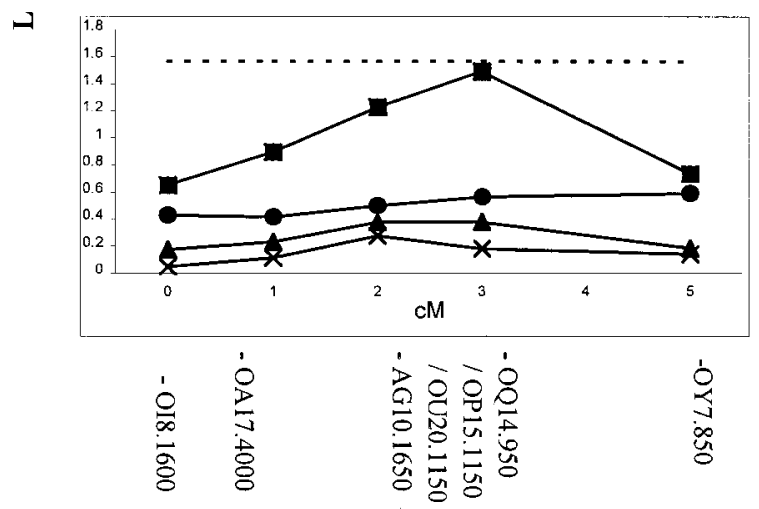

mapping (CIM), performed by QTL Cartographer version 1.15 (Basten et al., 1994, 2001), using the linkage map constructed with Mapmaker. Forward and backward analysis was used for the program SRmapqtl and Model 6 for Zmapqtl. Ten background markers and a window size of $10 \mathrm{cM}$ were specified in the analysis. Significant LOD threshold values were at the $P=0.05$ and were determined based on the permutation test (Churchill and

\section{E. LG2 Population 1 APP}

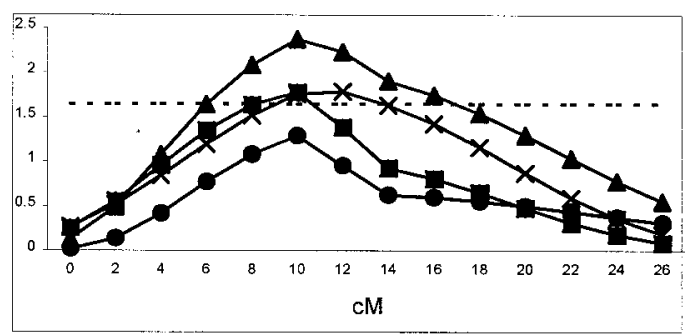

F.

LG2 Population 1 SPLT

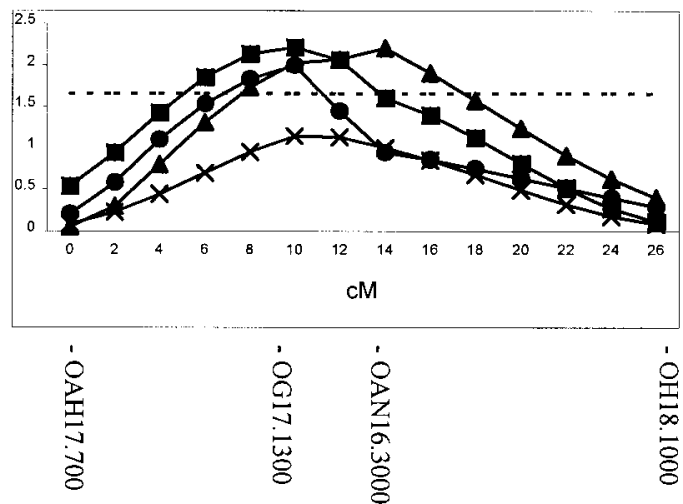

G. LG2 Population 2 APP

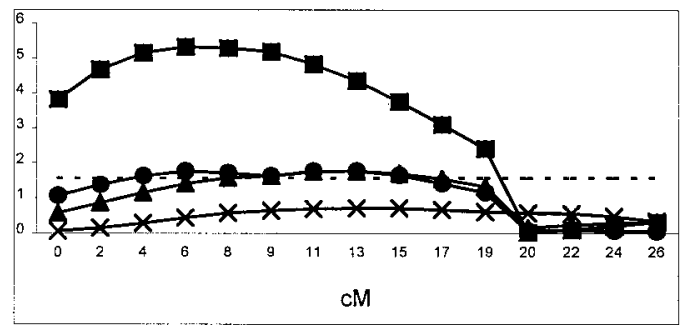

H. LG2 Population 2 SPLT

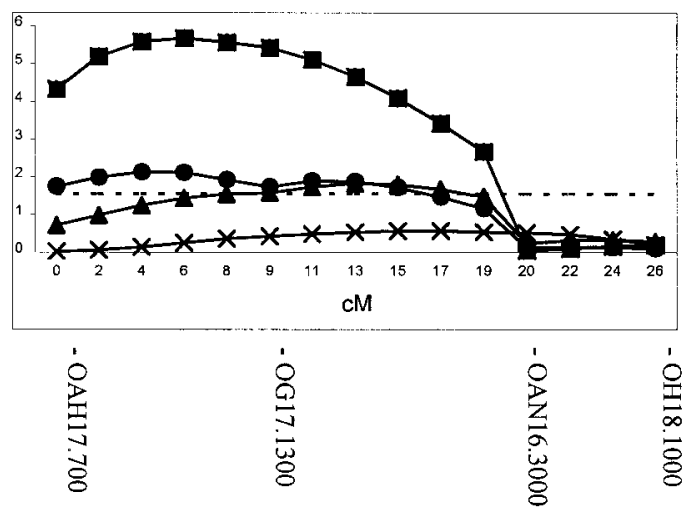

Fig. 1. Composite interval mapping (CIM) plots of appearance (APP) and degree of splitting (SPLT) of RILs of Populations 1 and 2 in the environments 1999-Mich, 1999-NDak and 1996-Minn, and averaged over the 6 environments in the study. LOD threshold values at 0.05 are shown as broken lines. 
Table 4. Proportion of variance $\left(\mathrm{R}^{2}\right)$ explained by QTL at linkage groups LG1 and LG2 and estimates of the additive effect, a, of the QTL on the appearance (APP) and degree of splitting (SPLT) of processed beans of Populations 1 and 2, planted in six environments.

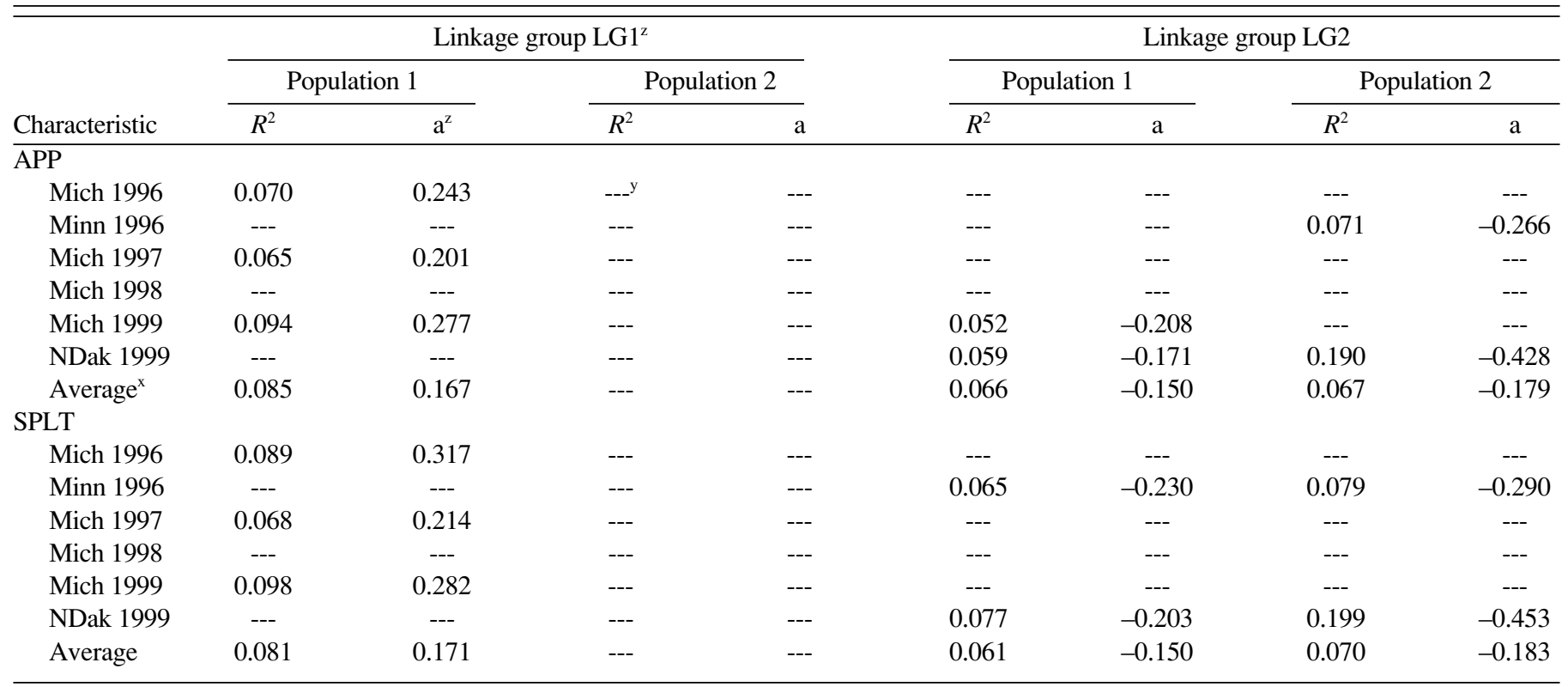

$\mathrm{z}_{\mathrm{a}}=$ estimate of the additive effect of allele derived from MCM.

${ }^{y}$ Nonsignificant, based on the LOD score threshold calculated through the permutation test.

${ }^{\mathrm{x}}$ Average $=$ averaged over all environments.

Doerge, 1994), with 1000 permutations for each test. The proportion of variance explained by the QTL and estimates of the additive effect were calculated using QTL Cartographer.

\section{Results and Discussion}

Mean squares for genotypes were significant for APP and SPLT for Populations 1 and 2 in each of the six environments (data not shown). Genotypic mean squares from combined analyses of variance were significant for the two traits despite significant environmental effects. The significant environmental effects led to significant genotype $\times$ environmental interactions (data not shown). Experimental variability was investigated further by examining variance component estimates (Table 1). The main interest was to examine the relative importance (percentage) of the genotypic $(\mathrm{G})$, genotype $\times$ year $(G \times Y)$, and genotype $\times$ environment $(G \times V)$ components. Means and ranges for APP of the parents and RILs are shown in Table 2. In most cases, the parents differed significantly for APP score (Table 2).

In all cases, the variance component for genotypes was greater than the environmental component for APP and accounted for $>25 \%$ of the total variance and ranged from $28 \%$ to $36 \%$ (Table 1). Although significant first order interactions of genotype $\times$ year and genotype $\times$ environment demonstrated a change in relationship among the lines, the genotypic variance component (Table 1) overshadowed the first-order interaction components, indicating that some RILs maintained their relative rankings across environments. Comparison of the performance of individual RILs indicated this fact (data not shown).

HERITABILITY ESTIMATES AND COEFFICIENTS OF CORRELATION. The narrow-sense heritability estimates for APP and SPLT were similar in both populations and were approaching high value $(\approx 0.90)$ (Table 3$)$. For Population 1 , the heritability estimates were 0.83 and 0.84 for APP and SPLT, respectively. For Population 2, APP and SPLT had a heritability of 0.85 .

The phenotypic coefficients of correlation between APP and
SPLT were similar in value and significant in each of the six environments, ranging from 0.94 to 0.97 and 0.91 to 0.97 in Populations 1 and 2, respectively (data not shown). Results of the QTL analysis for APP and SPLT reflected these high correlations. The plots of linkage map vs. LOD score for APP and SPLT from the CIM analyses had similarly shaped curves and were significant in the same environments (Fig. 1).

The appearance of canned beans is an indication of the appeal the processed product has toward the ideal preferred by processors and consumers. Although several factors influencing APP-such as brine clarity and the amount of starch in the brine and adhering to the surface of beans; the degree of clumping; and seed color, size and shape-are considered in evaluating the acceptability of canned kidney beans, the degree of splitting of the beans apparently plays a large role in the acceptance or rejection of a sample (Forney et al., 1990; Lu and Chang, 1996). The causes of splitting during processing are not known, although factors such as genotype, condition of the seed at harvest, and storage, harvesting, and handling procedures may affect the trait. The high positive correlations between APP and SPLT indicated that the use of one or the other trait rather than both could accurately predict the canning quality of kidney bean breeding lines.

DETECTION OF QTL FOR CANNING QUALITY TRAITS. The 14 primers that generated RAPD markers associated with canning quality traits in navy bean (Walters et al., 1997) were screened against the three kidney bean parents in the present study. We found no significant marker-trait associations with these markers in kidney bean either because of absence of polymorphism between the kidney bean parents or the lack of amplification products.

A different set of RAPD markers from those reported by Walters et al. (1997) were identified in the kidney bean populations. The results of single marker analysis on this new marker set, using simple linear regression, were similar to those obtained through composite interval mapping (CIM) and are not shown here. Plots from CIM for three environments, 1996-Minn, 1999-Mich, and 1999-NDak, and the mean averaged over all six environments are 
Table 5. RAPD markers, presence of marker alleles in parental genotypes, Montcalm (MCM), for dominant red color (oxblood) (Miklas et al., California Dark Red Kidney 82 (CDRK82), California Early Light Red Kidney (CELRK), and 2000; Smith, 1939, 1961 cited by Bassett, 1998), the average significant means for the appearance (APP) trait in Population 1 (MCM X CDRK82) and Population 2 (MCM x CELRK) in six environments.

\begin{tabular}{|c|c|c|c|c|c|}
\hline \multirow[t]{2}{*}{ Marker } & \multirow[t]{2}{*}{ Allele ${ }^{z}$} & \multicolumn{2}{|c|}{ Population $1^{\mathrm{w}}$} & \multicolumn{2}{|c|}{ Population $2^{\mathrm{w}}$} \\
\hline & & Source of allele & Average $\mathrm{APP}^{\mathrm{yx}}$ & Source of allele & Average $\mathrm{APP}^{\mathrm{yx}}$ \\
\hline \multicolumn{6}{|l|}{ LG1 Markers } \\
\hline \multirow[t]{2}{*}{ OY7.850 } & - & МСM & 3.4 & MCM & ns \\
\hline & + & CDRK 82 & 3.1 & CELRK & \\
\hline \multirow[t]{2}{*}{ OQ14.950 } & - & MCM & 3.5 & $\mathrm{MCM}$ & ns \\
\hline & + & CDRK 82 & 3.2 & CELRK & \\
\hline \multirow{2}{*}{ OP15.1150 } & - & МСМ & 3.5 & MCM & $\mathrm{ns}$ \\
\hline & + & CDRK 82 & 3.2 & CELRK & \\
\hline \multirow[t]{2}{*}{ OAG10.1650 } & - & МСM & 3.5 & $\mathrm{MCM}$ & ns \\
\hline & + & CDRK 82 & 3.2 & CELRK & \\
\hline \multirow[t]{2}{*}{ OA17.4000 } & + & МСМ & 3.4 & MCM & $\mathrm{ns}$ \\
\hline & - & CDRK 82 & 3.2 & CELRK & \\
\hline \multirow[t]{2}{*}{ OI8.1600 } & + & МCM & 3.4 & MCM & $\mathrm{ns}$ \\
\hline & - & CDRK 82 & 3.2 & CELRK & \\
\hline \multirow[t]{2}{*}{ OU20.1150 } & - & МСM & 3.4 & $\mathrm{MCM}$ & $\mathrm{ns}$ \\
\hline & + & CDRK 82 & 3.2 & CELRK & \\
\hline \multicolumn{6}{|l|}{ LG2 Markers } \\
\hline \multirow[t]{2}{*}{ OAH17.700 } & - & $\mathrm{MCM}$ & $\mathrm{ns}$ & $\mathrm{MCM}$ & $\mathrm{ns}$ \\
\hline & + & CDRK 82 & & CELRK & \\
\hline \multirow[t]{2}{*}{ OG17.1300 } & - & MCM & 3.2 & $\mathrm{MCM}$ & 3.2 \\
\hline & + & CDRK 82 & 3.4 & CELRK & 3.5 \\
\hline \multirow[t]{2}{*}{ OAN16.3000 } & - & $\mathrm{MCM}$ & 3.2 & $\mathrm{MCM}$ & 3.2 \\
\hline & + & CDRK 82 & 3.4 & CELRK & 3.5 \\
\hline \multirow[t]{2}{*}{ OH18.1000 } & + & MCM & $\mathrm{ns}$ & MCM & 3.2 \\
\hline & - & CDRK 82 & & CELRK & 3.5 \\
\hline
\end{tabular}

\footnotetext{
${ }^{z}$ Allele: $(-)=$ marker band is absent; $(+)=$ marker band is present

${ }^{\mathrm{y}} \mathrm{ns}=$ marker-trait association was not significant at level of significance $=0.05$.

${ }^{\mathrm{x}}$ Average APP $=$ APP scores averaged over the six environments

${ }^{\text {w }}$ High scores and high scoring-parents are in bold type.
}

shown in Fig. 1. The LOD thresholds shown are for the scores averaged over all environments. Two QTL conditioning both APP and SPLT in both populations were identified by CIM on two linkage groups, designated LG1 and LG2. LG1 consisted of seven markers-OQ14.950, OP15.1150, OAG10.1650, OY7.850, OI8.1600, OU20.1150, and OA17.400 — and spanned a total map distance of $24 \mathrm{cMin}$ Population 1 and $5 \mathrm{cM}$ in Population 2(Fig. 1AD). In Population 1, markers OP15.1150 and OAG10.1650 mapped to the same location. In Population 2, markers OU20.1150, OP15.1150 and OQ14.950 also mapped to the same location, and at a distance of $0.7 \mathrm{cM}$ from OAG10.1650. Aside from covering different total distances, the seven markers on LG1 displayed a different order between the two populations. LG2 consisted of four markers-OAH17.700, OG17.1300,OAN16.3000, and OH18.1000 - and covered a total of $26 \mathrm{cM}$ in both populations (Fig. 1E-H).

The map interval identified as LG1 was putatively located to linkage group B8 on the core map for P. vulgaris (Freyre et al., 1998), based on the presence of the markers OI8.1600/1500 and OU20.1150. The exact orientation of this linkage group on B8 could not be determined because of the different order of the marker OU20.1150 on the linkage maps of Populations 1 and 2 (Fig. 1). Several seed traits have been mapped to B8, namely, the Clocus for seedcoat pattern (McClean et al., 2002; Park et al., 2000), the $R$ gene and QTL associated with seed weight and length (Park et al., 2000).

The canning quality traits, APP and SPLT, were analyzed in six environments from 1996 to 1999. The marker-trait associations for both APP and SPLT in both populations were significant only in a subset of the six environments (Fig. 1; Table 4). In Population 1, a QTL for APP and SPLT was detected on LG1 in 1996-Mich (not shown in Fig. 1), 1997-Mich (not shown in Fig. 1), and 1999-Mich; the same QTL was not detected in 1996-Minn, 1998-Mich (not shown in Fig. 1) and 1999-NDak (Table 4; Fig. 1A and B). For the mean APP and SPLT scores, averaged across all environments, the presence of a QTL region on LG1 was detected in Population 1 (Table 4; Fig. 1A and B). The QTL explained $7 \%$ to $9 \%$ and $7 \%$ to $10 \%$ of the variance in APP and SPLT, respectively, in Population 1. In Population 2, no significant QTL for APP and SPLT were detected by CIM analysis in any environment. The additive effect of the MCM allele ranged from 0.17 to 0.28 for APP and 0.17 to 0.32 for SPLT in Population 1 (Table 4).

The QTL detected on LG2 had significant effects on APP in 1999-Mich and 1999-NDak in Population 1 (Table 4; Fig. 1E). For SPLT in Population 1, the QTL detected on LG2 was detected in the environments 1996-Minn and 1999-NDak (Table 4; Fig. 1F). In Population 2, a QTL was noted for both APP and SPLT in the environments 1996-Minn and 1999-NDak (Table 4; Fig. 1G and $\mathrm{H}$ ). The QTL controlling APP and SPLT was expressed across environments in both the dark red and light red kidney bean populations (Table 4; Fig. 1E to $\mathrm{H}$ ). The QTL detected on LG2 explained 5\% to 7\% and $6 \%$ to $8 \%$ of the variance in APP and SPLT, respectively, in Population 1 ; and $7 \%$ to $19 \%$ and $8 \%$ to $20 \%$ of the variance in APP and SPLT, respectively, in Population 2 (Table 4). The estimate of the additive effect of the allele from MCM on APP and SPLT ranged from -0.15 to -0.23 in Population 1 and from -0.18 to -0.45 in Population 2 (Table 4).

Based on the parental source of the alleles for each marker, the QTL detected on LG1 that was associated with desirable APP and SPLT was derived from MCM, the parent chosen in the study with the most desirable canning quality (Table 5). The major genes for desirable canning quality traits on LG2, however, appeared to be derived from CDRK 82 for Population 1 and CELRK for Population 2. We did not expect this result because genotypes with undesirable canning quality are, in general, not considered as a source of genes for improving canning quality traits. However, studies have shown that genotypes with undesirable characteristics, such as the wild relatives of crops, which are rarely used in the improvement of quantitative traits such as yield and quality, may in fact be used to improve these traits. For example, QTL from the phenotypically inferior wild rice relative, Oryza rufipogon, were used to improve grain yield in cultivated rice (Xiao et al., 1998), and QTL from unadapted tomato germplasm were used to improve color and soluble solids in cultivated tomato (Tanksley and Nelson, 1996). In 
the current study, CDRK 82 and CELRK appeared to possess the QTL for desirable APP and SPLT on LG2 (Table 5). The allele present in MCM on LG2 appeared to be associated with less desirable canning quality, as indicated by the negative additive effects on APP and SPLT noted for this parent (Table 4). The presence of alleles that are expressed only under particular environments (environment-specific) may explain why MCM had less than desirable (and less than expected) APP scores in 1997-Mich and in 1999-NDak. Unexpectedly, CELRK, which almost always manifests low APP scores $(\approx 3.0)$ in canning trials, regardless of the environment (Hosfield, personal observations), had higher scores than MCM in these two environments (Table 2).

Since the two populations used in this study had a common parent, and dark red and light red kidney beans are closely related market classes (Ghaderi et al., 1982), major genes for canning quality common to both populations were expected to be found. We observed this to be the case for the QTL on LG2, which was mapped on the genome of CDRK 82 and CELRK, the two parents developed and released by the California Agricultural Experiment Station. The putative QTL mapped to LG1 did not account for any significant variation in Population 2.

MARKERS FOR USE IN MARKER-ASSISTED SELECTION. Canned bean appearance in both dark red and light red kidney beans influence consumer choice. Poor canning quality in kidney bean is often the characteristic that prevents a high yielding, disease resistant, and otherwise agronomically superior line from becoming a cultivar. Hence, the importance of consumer and processor requirements makes the improvement of canning quality an important breeding objective for these market classes. Since selection for canning quality is labor-intensive, and requires a pilot-scale canning facility and $\approx 250 \mathrm{~g}$ of seed for testing, breeders are interested in alternatives to traditional selection strategies. The use of marker-assisted selection (MAS) could facilitate the evaluation of breeding lines in the seedling stage of a particular generation of testing. Since the traits in this study had high heritabilities, $>0.8$ for both populations, a combination of early-generation selection or pedigree selection would be preferable.

Based on our results, the use of only one marker for each QTL may be sufficient to effectively select for desirable canning quality traits in these populations. Considering the linkage data and CIM plots (Fig. 1) and the efficiency of using the least number of markers possible, the best markers to use for MAS appear to be OP15.1150 onLG1 and OG17.1300 onLG2. Single-marker analysis by ANOVA indicated that, among the markers in LG1, marker OP15.1150 accounted for the largest amount of variation in APP and SPLT in Population 1 (data not shown). Marker OG17.1300 similarly accounted for a relatively large amount of variation in APP and SPLT in both populations, compared to the other markers in LG2 (data not shown). The CIM plots (Fig. 1) likewise indicated evidence for a QTL affecting APP and SPLT at these marker locations. Our results indicate that these two markers have utility in selecting for canning quality in kidney bean breeding populations.

The markers identified in this study may be useful in indicating a genotype's potential for desirable canning quality, even before seed production, and in reducing the number of crosses needed to evaluate the trait (Dudley, 1993), particularly when MCM is used as a parent. The identification of such genotypes with superior canning quality represents continuing efforts to meet demands for high quality canned beans.

The use of MCM as a source of genes for the improvement of canning quality in kidney bean breeding programs seems justified by the results of this study. Our results also indicated that major genes for desirable canning quality traits may be present in genomes of cultivars with less desirable canning quality than MCM (e.g., CELRK). Further research using other DNA marker systems on both dark red and light red kidney beans may help to identify additional QTL associated with canning quality in these two market classes. Considering the low LOD threshold values we determined, larger populations may also be useful in refining the location of the major genes identified in our study and identifying other loci involved in the expression of canning quality.

\section{Literature Cited}

Adams, M.W. and C.L. Bedford. 1975. Breeding food legumes for improved processing and consumer acceptance properties. In: M. Milner (ed.). Nutritional improvement of food legumes by breeding. Proc. Symp. PAG, Rome, July 1972. Protein Advisory Group United Nations, New York.

Ariyarathne, H.M., D.P. Coyne, G. Jung, P.W. Skroch, A.K. Vidaver, J.R. Steadman, P.N. Miklas, and M.J. Bassett. 1999. Molecular mapping of disease resistance genes for halo blight, common bacterial blight, and bean common mosaic virus in a segregating population of common bean. J. Amer. Hort. Sci. 124:654-662.

Bassett, M.J. 1998. A test cross protocol for determining the genotype of dark red seedcoat colors in common bean. J. Amer. Soc. Hort. Sci. 123:1048-1052.

Basten, C.J., B.S. Weir, and Z.-B. Zeng. 1994. Zmap-a QTL cartographer, p. 65-66. In: C. Smith, J.S. Gavora, B. Benkel, J. Chesnais, W. Fairfull, J.P. Gibson, B.W. Kennedy, and E.B. Burnside (eds.). vol. 22. Proc. 5th World Congr. Genet. Appl. to Livestock Prod.: Computing Strategies and Software. Org. Comm., 5th World Congr. Genet. Appl. to Livestock Prod., Guelph, Ontario, Canada.

Basten, C.J., B.S. Weir, and Z.-B. Zeng. 2001. QTL Cartographer, version 1.15. N.C. State Univ., Raleigh.

Churchill, G.A. and R.W. Doerge. 1994. Empirical threshold value for quantitative trait mapping. Genetics 138:963-971.

Copeland, L.O. and M.H. Erdmann. 1977. Montcalm and Mecosta: Halo blight (Pseudomonas phaseolicola) tolerant kidney bean varieties for Michigan. Mich. State Univ. Coop. Ext. Serv. Bul. 957 No. 81.

Dudley,J.V. 1993. Molecular markers in plant improvement: manipulation of genes affecting quantitative traits. Crop Sci. 33:660-668.

Fehr, W.R. 1987. Principles of cultivar development. vol. 1. Theory and technique. MacMillan, New York.

Forney, A.K., D.E. Halseth, and K.C. Kelly. 1990. Quality of canned "Ruddy" kidney beans as influenced by planting date, harvest time and length of storage before canning. J. Amer. Soc. Hort. Sci. 115:10511054.

Freyre, R., P.W. Skroch, V. Geffroy, A.-F. Adam-Blondon, A. Shirmohamadali, W.C. Johnson, V. Llaca, R.O. Nodari, P.A. Pereira, S.M. Tsai, J. Tohme, M. Dron, J. Nienhuis, C.E. Vallejos, and P. Gepts. 1998. Towards an integrated linkage map of common bean: 4. Development of a core linkage map and alignment of RFLP maps. Theor. Appl. Genet. 97:847-856.

Ghaderi, A., M.W. Adams, and A.W. Saettler. 1982. Environmental response patterns in commercial classes of common bean (Phaseolus vulgaris L.). Theor. Appl. Genet. 63:17-22.

Hallauer, A.R. and J.B. Miranda. 1988. Quantitative genetics in maize breeding. Iowa State Univ. Press, Ames, Iowa.

Hosfield, G.L. 1991. Genetic control of production and food quality factors in dry bean. Food Technol. 45:98-103.

Hosfield, G.L. and M.A. Uebersax. 1980. Variability in physico-chemical properties and nutritional components of tropical and domestic dry bean (Phaseolus vulgaris) germplasm. J. Amer. Soc. Hort. Sci. 105:246-252. Hosfield, G.L. and M.A. Uebersax. 1990. Culinary quality in dry bean: can it be improved?. Annu. Rpt. Bean Improvement Coop. 33:17-18.

Hosfield, G.L., A. Ghaderi, and M.A. Uebersax. 1984a. A factor analysis of yield and sensory and physico-chemical data from tests used to measure culinary quality in dry edible beans (Phaseolus vulgaris). Can. J. Plant Sci. 64:285-294. 
Hosfield, G.L., M.A. Uebersax, and T.G. Isleib. 1984b. Seasonal and genotypic effects on yield and physico-chemical characteristics related to food quality in dry, edible beans (Phaseolus vulgaris). J. Amer. Soc. Hort. Sci. 109:182-189.

Jung, G., P.W., Skroch, J. Nienhuis, D.P. Coyne, E. Arnaud-Santana, H.M. Ariyarathne, and J.M. Marita. 1999. Confirmation of QTL associated with common bacterial blight resistance in four different genetic backgrounds in common bean. Crop Sci. 39:1448-1455.

Kelly, J.D. and P.N. Miklas. 1998. The role of RAPD markers in breeding for disease resistance in common bean. Mol. Breed. 4:1-11.

Knapp, S.J., W.W. Stroup, and W. M. Ross. 1985. Exact confidence intervals for heritability on a progeny mean basis. Crop Sci. 25:192-194.

Kosambi, D.D. 1944. The estimation of map distances from recombination values. Ann. Eugen. 12:172-175.

Lander, E.S., P. Green, J. Abrahamson, A. Barlow, M.J. Daly, S.E. Lincoln, and I. Newburg. 1987. Mapmaker: an interactive computer package for constructing primary genetic linkage maps of experimental and natural populations. Genomics. 1:174-181.

Lu, W. and K.C. Chang. 1996. Correlations between chemical composition and canning quality attributes of navy bean (Phaseolus vulgaris L.). Cereal Chem. 73:785-787.

Lucier,G., B-H. Lin, J. Allshouse, and L.S. Kantor. 2000. Factors affecting dry bean consumption in the United States. Vegetables and Specialties S \& O NGS-280/April,www.ers.usda.gov/Briefing/Drybeans/DBnDemand.pdf.

McClean, P.E., R.K. Lee, C. Otto, P. Gepts, and M.J. Bassett. 2002. Molecular and phenotypic mapping of genes controlling seed coat pattern and color in common bean (Phaseolus vulgaris L.). J. Hered. (in press).

Miklas, P.N., E. Johnson, V. Stone, J.S. Beaver, C. Montoya, and M. Zapata. 1996. Selective mapping of QTL conditioning disease resistance in common bean. Crop Sci. 36:1344-1351.

Miklas, P.N., V. Stone, C.A. Urrea, E. Johnson, and J.S. Beaver. 1998. Inheritance and QTL analysis of field resistance to ashy stem blight in common bean. Crop Sci. 38:916-921.

Miklas, P.N., R. Delorme, V.Stone, M.J. Daly, J.R. Stavely, J.R. Steadman, M.J. Bassett, and J.S. Beaver. 2000. Bacterial, fungal, and viral disease resistance loci mapped in a recombinant inbred common bean population ('Dorado'/XAN 176). J. Amer. Soc. Hort. Sci. 125:476-481.

Miklas, P.N., W.C. Johnson, R. Delorme, and P. Gepts. 2001. QTL conditioning physiological resistance and avoidance to white mold in dry bean. Crop Sci. 41:309-315.
Park, S.O., D.P. Coyne, N. Mutlu, G. Jung, and J.R. Steadman. 1999. Confirmation of molecular markers and flower color associated with QTL for resistance to common bacterial blight in common beans. J. Amer. Soc. Hort. Sci. 124:519-526.

Park, S.O., D.P. Coyne, G. Jung, P.W. Skroch, E. Arnaud-Santana, J.R. Steadman, H.M. Ariyarathne, and J. Nienhuis. 2000. Mapping of QTL for seed size and shape traits in common bean. J. Amer. Soc. Hort. Sci. 125:466-475.

Park, S.O., D.P. Coyne, J.R. Steadman, and P.W. Skroch. 2001. Mapping of QTL for resistance to white mold disease in common bean. Crop Sci. 41:1253-1262.

Smith, F.L. 1939. A genetic analysis of red seed-coat color in Phaseolus vulgaris. Hilgardia 12:553-621, as cited by M.J. Bassett. 1998. A test cross protocol for determining the genotype of dark red seedcoat colors in common bean. J. Amer. Soc. Hort. Sci. 123:1048-1052.

Smith, F.L. 1961. Seed-coat color genes in six commercial varieties of beans. Hilgardia 31:1-14, as cited by M.J. Bassett. 1998. A test cross protocol for determining the genotype of dark red seedcoat colors in common bean. J. Amer. Soc. Hort. Sci. 123:1048-1052.

Tanksley, S.D. and J.C. Nelson. 1996. Advanced backcross QTL analysis: A method for the simultaneous discovery and transfer of valuable QTLs from unadapted germplasm into elite breeding lines. Theor. App. Genet. 92:191-203.

Uebersax, M.A. and C.L. Bedford. 1980. Navy bean processing: Effect of storage and soaking methods on quality of canned beans. MSU Agr. Expt. Sta., E. Lansing Res. Rpt. 410.

Walters, K.J., G.L. Hosfield, M.A. Uebersax, and J.D. Kelly. 1997. Navy bean canning quality: Correlations, heritability estimates, and randomly amplified polymorphic DNA markers associated with component traits. J. Amer. Soc. Hort. Sci. 122:338-343.

Wassimi, N.N., G.L. Hosfield, and M.A. Uebersax. 1990. Inheritance of physico-chemical seed characters related to culinary quality in dry bean. J. Amer. Soc. Hort. Sci. 115:492-499.

Williams, J.G.K., A.R. Kubelik, K.J.Livak, J.A. Rafalski, and S.V. Tingey. 1990. DNA polymorphisms amplified by arbitrary primers are useful as genetic markers. Nucleic Acids Res. 18:6531-6536.

Xiao, J., J. Li, S. Grandillo, S.N. Ahn, L. Yuan, S.D. Tanksley, and S.R. McCouch. 1998. Identification of trait-improving quantitative trait loci alleles from a wild rice relative, Oryza rufipogon. Genetics 150:899-909. 